\title{
ПОВЕДІНКОВА ЕКОНОМІКА
}

\author{
УДК 330.33
}

\author{
PARIMAL CHANDRA BISWAS ${ }^{1 *}$, DILIP KUMAR CHAKRABORTY ${ }^{2 *}$ \\ 1* Ph.D., Professor, School of Management, Adamas University, Kolkata, India \\ 2* Ph.D. Research Scholar, Adamas University, Kolkata, India
}

\section{A STUDY OF ORGANIZATIONAL CULTURE IN MANUFACTURING INDUSTRIES IN THE ROYAL KINGDOM OF BHUTAN}

\begin{abstract}
Research Objectives. The researchers have put following major objectives in the study, which contribute to Industrial Relations, Human Resource Management and overall performance of the manufacturing industries in Bhutan. 1. To study Organizational Culture (OC) in manufacturing industries in Bhutan. 2. To do comparative analysis of OC in manufacturing industries of different ownership in Bhutan. Research Results. Study of OC show that "Human Relations" culture in the companies is at high level though "Rational Goal" culture and "Internal Process" culture needs to be changed for better because the way how organizations do things has never changed very much. They do not have cultivated properly "Open Systems" culture. The comparative analysis of OC in three manufacturing industries of different ownership shows that "Human Relations", "Rational Goal", "Internal Process" cultures are better cultivated in the private company than in both of the government owned company and the Joint venture. Practical Significance of the Research. The practical significance of the work lies in the fact that the results of the research can be used to reorient the Industrial Relations and Human Resource Management practices in Bhutan towards an innovative path of development. Innovative ideas, practices and recommendations in the study can be used to improve the Organizational Culture , Organizational Behavior, Industrial Relations, which will lead to better performance of the company in terms of higher efficiency and effectiveness on the one hand and on the other hand higher social and emotional well-being of employees, which are the part of national goal of GNH in Bhutan. The results of the research are of interest to Industrial Relations' specialists, lawyers, as well as for management people, who are engaged in collective agreement practices and social regulation of labor Relations. Research materials can be used in the process of teaching Personnel Management, Industrial Relations, Organizational behavior and other applied disciplines.
\end{abstract}

Keywords: Bhutan, Organizational Culture, Human Relations, manufacturing industries

\section{Research Problem Identification}

Despite the relatively strong legal framework for manufacturing industries regulations in Bhutan, working conditions are not so much developed. The results have been accidents, injuries and fatalities among people. Wages and salary level are not high. On the other hand there is no social unrest or labor strikes found in Bhutan. Having in view of the apparently conflicting views of the Industrial Relations practices of manufacturing industries the researchers have undertaken the task to understand organizational culture at the manufacturing industries.

\section{Literature Review}

Relatively little is known about Bhutan. According to Gallenkamp (2011, p.1) the kingdom of Bhutan is perhaps the most understudied country in South Asia. Few scholars like O'Flynn and Blackman (2009), Blackman et al. (2010), Turner, Chuki, and Tshering (2011), and Ugyel (2014) have done their research on Human Resource Management of the Bhutanese Civil Service. But the literature is silent on study of Organizational Culture in manufacturing industries in Bhutan.

\section{Research Design}

The researchers have studied Organizational Culture (OC) practices in nine manufacturing industries of different ownerships in Bhutan using one set of questionnaires. Total respondents were 294 people including managers and employees. The questionnaires were framed and structured using 5 Point Likert Scale. For comparative analysis only three manufacturing industries of different ownership have been chosen for the study. 
Review of transport economics and management, 2020, вип. 3(19)

For each attribute of the Questionnaire, the Neither Agree nor Disagree - indicated by 3 common 5 point rating scale goes like this:

Strongly Disagree $\quad-\quad$ indicated by 1

Disagree

Agree

Strongly Agree indicated by 4 indicated by 5

Table 1

Questionnaire for studying Organizational Culture (OC)

\begin{tabular}{|c|c|}
\hline Attributes & Questions \\
\hline OC1 & Important information is often not communicated to people. \\
\hline OC2 & People usually receive feedback on the quality of work they have done. \\
\hline OC3 & This company is considerate towards its employees. \\
\hline OC4 & Supervisors show an understanding of the people who work for them. \\
\hline OC5 & Everything has to be done according to the book. \\
\hline OC6 & People are prepared to make a special effort to do a good job. \\
\hline OC7 & People here are under pressure to meet targets. \\
\hline OC8 & People have a good understanding of what the organization is trying to do. \\
\hline OC9 & Poor scheduling and planning often results in targets not being met. \\
\hline OC10 & The way this organization does things has never changed very much. \\
\hline OC11 & There is a lot of support for new ideas here. \\
\hline OC12 & Management here are quick to spot the need to do things differently. \\
\hline OC13 & People are strongly encouraged to develop their skills. \\
\hline OC14 & In this organization, time is taken to review organizational objectives \\
\hline OC15 & the market place. \\
\hline OC16 & OC17
\end{tabular}

\section{Research Findings}

\section{Study of Organizational Culture by main domains}

Cameron and Quinn's (1988) 'Competing Values Framework' suggests that there are a range of values and priorities that determine and influence a community's culture. Quinn identifies four main domains of organizational culture: Human Relations, Rational Goal, Internal Process and Open Systems. We have segmented all the questions for studying Organization Culture into four domains for further analysis.
"Human Relations" culture in the companies is cultivated at high level as $76 \%$ respondents agree that their supervisors show an understanding of the people who work for them. "Rational Goal" culture needs to be developed as $62 \%$ respondents believe that people here are under pressure to meet targets. "Internal process" culture needs to be changed for better as $42 \%$ respondents agree that the way organizations do things has never changed very much. $69 \%$ respondents believe that their organizations are quite inward looking and they do not concern with what is happening in the market place. It shows that they do not have cultivated properly "Open systems" culture. 
Survey of Organizational Culture (OC) by main domains

\begin{tabular}{|c|c|c|c|c|}
\hline $\begin{array}{l}\text { Main } \\
\text { Domains }\end{array}$ & Questions & $\begin{array}{c}\text { Total } \\
\text { Agree, } \\
\%\end{array}$ & $\begin{array}{c}\text { Total } \\
\text { Disagree, } \\
\%\end{array}$ & $\begin{array}{l}\text { Neutral, } \\
\quad \%\end{array}$ \\
\hline \multirow{5}{*}{$\begin{array}{l}\text { Human } \\
\text { Relations } \\
\text { Culture }\end{array}$} & $\begin{array}{l}\text { OC2 People usually receive feedback on the quality of } \\
\text { work they have done. }\end{array}$ & 74 & 11 & 15 \\
\hline & $\begin{array}{c}\text { OC3 This company is considerate towards its } \\
\text { employees. }\end{array}$ & 71 & 12 & 17 \\
\hline & $\begin{array}{l}\text { OC4 Supervisors show an understanding of the people } \\
\text { who work for them. }\end{array}$ & 76 & 10 & 14 \\
\hline & $\begin{array}{l}\text { OC14 Management here are quick to spot the need to } \\
\text { do things differently. }\end{array}$ & 65 & 14 & 21 \\
\hline & OC15 People are strongly encouraged to develop their skills. & 75 & 11 & 14 \\
\hline \multirow{5}{*}{$\begin{array}{l}\text { Rational } \\
\text { Goal Culture }\end{array}$} & OC7 Quality is taken very seriously here. & 79 & 10 & 11 \\
\hline & $\begin{array}{l}\text { OC8 People are prepared to make a special effort to do } \\
\text { a good job. }\end{array}$ & 79 & 9 & 12 \\
\hline & OC9 People here are under pressure to meet targets. & 62 & 18 & 20 \\
\hline & $\begin{array}{c}\text { OC10 People have a good understanding of what the } \\
\text { organization is trying to do. }\end{array}$ & 65 & 15 & 20 \\
\hline & $\begin{array}{l}\text { OC16 In this organization, time is taken to review } \\
\text { organizational objectives. }\end{array}$ & 27 & 53 & 20 \\
\hline \multirow{5}{*}{$\begin{array}{l}\text { Internal } \\
\text { Process } \\
\text { culture }\end{array}$} & $\begin{array}{l}\text { OC1 Important information is often not communicated } \\
\text { to people. }\end{array}$ & 37 & 48 & 15 \\
\hline & OC5 Everything has to be done according to the book. & 77 & 16 & 7 \\
\hline & $\begin{array}{l}\text { OC6 People are given adequate scope to do their jobs } \\
\text { properly. }\end{array}$ & 68 & 14 & 18 \\
\hline & $\begin{array}{l}\text { OC11 Poor scheduling and planning often results in } \\
\text { targets not being met. }\end{array}$ & 37 & 30 & 33 \\
\hline & $\begin{array}{c}\text { OC12 The way this organization does things has never } \\
\text { changed very much. }\end{array}$ & 43 & 36 & 21 \\
\hline \multirow{2}{*}{$\begin{array}{c}\text { Open } \\
\text { Systems } \\
\text { culture }\end{array}$} & OC13 There is a lot of support for new ideas here. & 65 & 13 & 22 \\
\hline & $\begin{array}{l}\text { OC17 This organization is quite inward looking; it does } \\
\text { not concern itself with what is happening in the market } \\
\text { place. }\end{array}$ & 69 & 10 & 21 \\
\hline
\end{tabular}

\section{Comparative analysis of Organizational Culture in industries of different ownership}

"Human Relations" culture in the Private company Lhaki Steel is developed comparably at the higher level than in the government owned company BBPL and in the joint venture BFAL as per answers of the respondents. $86 \%$ respondents agree that their company is considerate towards its employees (OC3) in Lhaki Steel, 60\% support that idea in BBPL and only 50\% in BFAL. $87 \%$ respondents believe that Supervisors show an understanding of the people who work for them (OC4) in BBPL, 86\% respondents in Lhaki Steel and only $65 \%$ in BFAL.
"Rational Goal" Culture in the Private company Lhaki Steel is better cultivated than in both of the government owned company BBPL and the joint venture BFAL as respondents answered. 97\% respondents in Lhaki Steel believe that Quality is taken very seriously in their company (OC7), whereas it is supported by $77 \%$ in BBPL and $75 \%$ in BFAL. $72 \%$ respondents agree that people have a good understanding of what the organization is trying to do (OC10) in Lhaki Steel, whereas $60 \%$ respondents support that idea in BBPL and only $53 \%$ in BFAL. 
Survey of Organizational Culture (OC) in manufacturing industries of different ownership

\begin{tabular}{|c|c|c|c|c|c|c|c|c|c|c|}
\hline \multirow{2}{*}{ Main Domains } & \multirow{2}{*}{ Questions } & \multicolumn{3}{|c|}{$\begin{array}{c}\text { Government } \\
\text { Company BBPL }\end{array}$} & \multicolumn{3}{|c|}{$\begin{array}{c}\text { Private Company } \\
\text { Lhaki Steel }\end{array}$} & \multicolumn{3}{|c|}{ Joint Venture BFAL } \\
\hline & & $\begin{array}{l}\text { TA } \\
(\%)\end{array}$ & $\begin{array}{l}\mathrm{TD} \\
(\%)\end{array}$ & $\begin{array}{l}\mathrm{N} \\
(\%)\end{array}$ & $\begin{array}{l}\text { TA } \\
(\%)\end{array}$ & $\begin{array}{l}\mathrm{TD} \\
(\%)\end{array}$ & $\begin{array}{l}\mathrm{N} \\
(\%)\end{array}$ & $\begin{array}{l}\text { TA } \\
(\%)\end{array}$ & $\begin{array}{l}\mathrm{TD} \\
(\%)\end{array}$ & $\begin{array}{l}\mathrm{N} \\
(\%)\end{array}$ \\
\hline \multirow{5}{*}{$\begin{array}{l}\text { Human relationns } \\
\text { Culture }\end{array}$} & OC 2. & 63 & 20 & 17 & 69 & 10 & 21 & 62 & 13 & 25 \\
\hline & OC 3 & 60 & 13 & 27 & 86 & 14 & 0 & 50 & 23 & 27 \\
\hline & OC 4 & 87 & 0 & 13 & 86 & 7 & 7 & 65 & 18 & 17 \\
\hline & OC 14 & 50 & 33 & 17 & 72 & 0 & 28 & 45 & 15 & 40 \\
\hline & OC 15 & 73 & 10 & 17 & 76 & 0 & 24 & 58 & 22 & 20 \\
\hline \multirow{5}{*}{$\begin{array}{l}\text { Ration al Goals } \\
\text { Culture }\end{array}$} & OC 7 & 77 & 7 & 16 & 97 & 0 & 3 & 75 & 15 & 10 \\
\hline & OC 8 & 90 & 3 & 7 & 90 & 0 & 10 & 55 & 28 & 17 \\
\hline & OC 9 & 83 & 3 & 14 & 63 & 13 & 24 & 55 & 10 & 35 \\
\hline & OC 10 & 73 & 20 & 7 & 83 & 17 & 0 & 32 & 30 & 38 \\
\hline & OC 16 & 27 & 57 & 16 & 21 & 52 & 27 & 30 & 40 & 30 \\
\hline \multirow{5}{*}{$\begin{array}{c}\text { Internal } \\
\text { ProcessCulture }\end{array}$} & OC 1 & 40 & 47 & 13 & 38 & 62 & 0 & 32 & 48 & 20 \\
\hline & OC 5 & 27 & 13 & 60 & 69 & 21 & 10 & 55 & 13 & 32 \\
\hline & OC 6 & 60 & 17 & 23 & 72 & 11 & 17 & 53 & 17 & 30 \\
\hline & OC 11 & 53 & 33 & 14 & 38 & 17 & 45 & 35 & 33 & 32 \\
\hline & OC 12 & 43 & 37 & 20 & 34 & 24 & 42 & 48 & 27 & 25 \\
\hline \multirow{2}{*}{$\begin{array}{c}\text { Open System } \\
\text { Culture }\end{array}$} & OC 13 & 53 & 27 & 20 & 69 & 7 & 24 & 50 & 18 & 32 \\
\hline & OC 17 & 64 & 3 & 33 & 66 & 10 & 24 & 53 & 15 & 32 \\
\hline
\end{tabular}

Note: BBPL : Bhutan Boards Products Limited, Govt Owned Company

Lhaki Steel Private Limited Company

BFAL : Bhutan Ferro Alloys Limited, Joint Venture Company

TA: Total Agreed, TD: Total Disagreed, N: Neutral

"Internal Process" culture in the Private company Lhaki Steel is established comparably at the higher level than in the government owned company BBPL and in the joint venture BFAL as respondents gave their feedback. $62 \%$ respondents support that important information is communicated to people (OC1) in Lhaki Steel, whereas it is supported by $47 \%$ respondents in BBPL and $48 \%$ respondents in BFAL. 83\% respondents agree that People are given adequate scope to do their jobs properly (OC6) in Lhaki

\section{Conclusions}

Due to good human relations among people, rooted in their national culture employees cope with life challenges more softly in order to keep and support harmony with one another and pursues happiness in life in this wonderful country. With minimum level of salaries, wages, moderate working conditions, less economic and social benefits they are content with their jobs and
Steel, whereas $73 \%$ respondents support that idea in BBPL and only $32 \%$ in BFAL.

"Open System" culture is not cultivated properly either in the Private company Lhaki Steel or in the government owned company BBPL and in the joint venture BFAL as respondents gave their answers. 66\% respondents in Lhaki Steel agree that there organization is quite inward looking and it does not concern itself with what is happening in the market place (OC17), whereas $64 \%$ respondents support that idea in BBPL and $53 \%$ in BFAL.

management people. The comparative analysis of organization culture in manufacturing industries of different ownership shows that the private company is practicing better Organizational Culture than both of the government owned company and the Joint venture. The research proves that Bhutan is a peace seeking country and it pursues successfully Gross National Happiness as their national goal. 


\section{REFERENCES}

1. Gallenkamp, M. (2011). The history of institutional change in the kingdom of Bhutan: A tale of vision, resolve, and power. Heidelberg Papers in South Asian and Comparative Politics, 61, 1-21.

2. Turner, M., and J, Tshering (2014), Is Democracy Being Consolidated in Bhutan? Asian Poltics \& Policy Journal Vol.6(3):pp.413-31

3. Tshering Yangden (2009), Gender, Culture and Development: In the Paradigm of Gross National Happiness in Bhutan, School of Social and Political Sciences, University of Canterbury, Christchurch, New Zealand.

4. Ugyen Tshewang (2015), Civil Service HRM Reforms in a new Democracy: The case of Bhutan, School of Management, QUT School of Business, Queensland University of Technology, Brisbane, Queensland, Australia.

5. Gross National Happiness Commission (2013). Eleventh Five Year Plan (2013-2018): Main document- self reliance and inclusive socio-economic development. Thimphu: GNH. Retrieved from http://www.gnhc.gov.bt/wpcontent/ uploads/2011/04/Eleventh-Five-Year-Plan.pdf.

6. Kelly, A. (2012). Gross national happiness in Bhutan: the big idea from a tiny state that could change the world. The Guardian. Disponível em: http://www. The guardian. com/world/2012/dec/01/bhutan-wealth-happiness-counts. 7. Labour and Employment Act of Bhutan (2007). Retrieved from https://www.wipo.int/edocs/lexdocs/laws/en/bt/bt021en.pdf.

8. Batston, E. (1988), The Reform of Workplace Industrial Relations: Theory, Myth and Evidence, Clarendon Press, Oxford.

9. Chalmers, Norma J. (1989), Industrial Relations in Japan: The Peripheral Workforce, Routledge.

10. Clegg, H.A. (1979), The Changing System of Industrial Relations in Great Britain, Basil Blackwell, Oxford.

11. Goodman, John (1985), Employment Relations in Industrial Society, Heritage Publishers, New Delhi.

12. Katz, H.C. and Kochan, T.A. (2000) An Introduction to Collective Bargaining and Industrial Relations. Irwin McGraw-Hill.

Стаття надійшла до редакції: 24.04.2020

Received: 24 April 2020 